\title{
Comparison of the Adsorption Ability of MgAl-HC, CaAl-HC, and ZaAl-HC Composite Materials Based on Duku Peel Hydrochar in Adsorption of Direct Green Anionic Dyes
}

\author{
Novie Juleanti ${ }^{1}$, Normah Normah ${ }^{1}$, Patimah Mega Syah Bahar Nur Siregar ${ }^{1}$, Alfan Wijaya ${ }^{1}$, Neza \\ Rahayu Palapa ${ }^{2}$, Tarmizi Taher ${ }^{3,4}$, Nurlisa Hidayati ${ }^{4}$, Risfidian Mohadi ${ }^{4}$, and Aldes Lesbani ${ }^{2,4^{*}}$ \\ ${ }^{1}$ Magister Program, Faculty of Mathematics and Natural Sciences, Sriwijaya University, \\ Jl. Padang Selasa No. 524, Ilir Barat 1, Palembang 30139, South Sumatra, Indonesia \\ ${ }^{2}$ Graduate School, Faculty of Mathematics and Natural Sciences, Sriwijaya University, \\ Jl. Palembang-Prabumulih Km. 90-32, Ogan Ilir 30862, South Sumatra, Indonesia
}

${ }^{3}$ Department of Environmental Engineering, Faculty of Mathematics and Natural Sciences, Institut Teknologi Sumatera, Jl. Terusan Ryacudu, Way Hui, Jati Agung, Lampung 35365, Indonesia

${ }^{4}$ Research Center of Inorganic Materials and Complexes, Faculty of Mathematics and Natural Sciences, Sriwijaya University, Jl. Padang Selasa, Bukit Besar, Palembang 30139, South Sumatera, Indonesia

\section{*Corresponding author:}

email:aldeslesbani@pps.unsri.ac.id

Received: August 27, 2021

Accepted: November 14, 2021

DOI: $10.22146 / \mathrm{ijc} .68719$

\begin{abstract}
Preparation of composite material from layered double hydroxide $(L D H)$ with hydrochar (HC) from duku peel produces CaAl-HC, MgAl-HC, and ZnAl-HC have shown the success of the preparation process as evidenced by characterizations such as $X R D$ and FT-IR. The XRD characterization data evidenced the typical diffraction of the hydrochar around $2 \theta=20^{\circ}$ in the composite material. FTIR analysis is a characterization that supports the success of composite materials, which showed the presence of typical vibrations of $\mathrm{HC}$ at 3245, 2931, and $1635 \mathrm{~cm}^{-1}$ contained in the composite spectrum. The application of MgAl-HC, CaAl-HC, and ZnAl-HC composites as adsorbents showed $\mathrm{Q}_{\max }$ (adsorption ability) values of $94.340 \mathrm{mg} / \mathrm{g}, 128.205 \mathrm{mg} / \mathrm{g}$, and $89.286 \mathrm{mg} / \mathrm{g}$. Overall the adsorption process is endothermic with a positive enthalpy value, and a negative Gibbs free energy value indicates a spontaneous adsorption process. The isotherm model of $\mathrm{MgAl}-\mathrm{HC}$, CaAl-HC, and ZnAl-HC show that the Langmuir isotherm model is more dominant, as indicated by the $R^{2}$ value closer to 1 which indicates that the adsorption process takes place in a monolayer.
\end{abstract}

Keywords: duku peel; hydrochar; adsorption; regeneration; dyes

\section{- INTRODUCTION}

Lately, synthetic dyes have been in great demand in textiles, printing, paper, food, and pharmaceuticals. Synthetic dyes consist of cationic and anionic dyes, but most industries prefer the use of anionic dyes. Synthetic dyes are widely used as a substitute for natural dyes, which are unstable, and quickly decompose under sunlight, and the storage process must be precise. Synthetic dyes are the right choice because they are stable, do not break down quickly, and have many color variations [1].

Some of the advantages obtained from dyes can lead to uncontrolled use. Excessive use of dyes will harm the environment. Synthetic textile dyes have a complex aromatic molecular structure that makes them difficult to break down when disposed of in the ecosystem [2], which makes necessary efforts to overcome these harmful effects. Many methods can be used, such as ion exchange [3], biodegradation [4], chemical coagulation [5], catalytic reduction [6], and adsorption [7].

According to Milagres et al., adsorption is the most promising method for dealing with contamination, with an economic value, easy to do, and very efficient, making adsorption the suitable method for dealing with contamination [8]. Adsorption is an effective and

Novie Juleanti et al. 
practical method for treating polluted water dyes due to its high efficiency, simplicity, and availability of many adsorbents [2]. Some adsorbents widely used for adsorption include activated carbon, graphene, zeolites, polymers, clays, and layered double hydroxides.

Layered double hydroxide is a natural inorganic lamellar compound that can be easily synthesized. Some of the advantages of layered double hydroxide that are the current attraction, such as large surface area [9], ion exchangeability [10], and can be regenerated [11], make this material continues to be developed. Layered double hydroxide has the general formula $\left[\mathrm{M}^{2+}{ }_{1-\mathrm{x}} \mathrm{M}^{3+}{ }_{\mathrm{x}-}(\mathrm{OH})_{2}\right]^{\mathrm{x}+}$

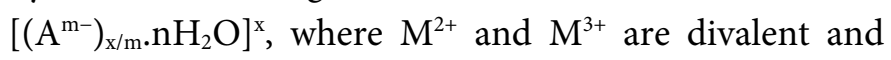
trivalent cations, and $\mathrm{A}^{\mathrm{m}-}$ is charge balancing interlayer anion [9].

Layered double hydroxide (LDH) is a material that can be modified by intercalation and composite. The use of $\mathrm{LDH}$ as a composite can increase the $\mathrm{Q}_{\max }$ of the material. This ability makes LDH-based composite materials an effective adsorbent to overcome contamination [13]. The adsorption ability of MgAl composites has been demonstrated in several studies. Badri et al. [12] studied rhodamine- $\mathrm{B}$ and methylene blue adsorption using MgAlBiochar. The $\mathrm{Q}_{\max }$ obtained from the adsorption process was 38.49 and $91.44 \mathrm{mg} / \mathrm{g}$, respectively. Another study conducted by $\mathrm{He}$ et al. [13] using the $\mathrm{MgAl}-\mathrm{HC}$ composite as a phosphate adsorbent resulted in a $\mathrm{Q}_{\max }$ of $41.16 \mathrm{mg} / \mathrm{g}$.

In this study, the direct green (DG) dye adsorption process was carried out using MgAl-HC, CaAl-HC, and $\mathrm{ZnAl}-\mathrm{HC}$. The success of material preparation is proven through XRD, FT-IR, and SEM characterization data. The adsorption ability of MgAl-HC, CaAl-HC, and ZnAl-HC composites was confirmed by several parameters: regeneration, selectivity, kinetics, isotherm, and thermodynamics.

\section{- EXPERIMENTAL SECTION}

\section{Materials}

The chemicals used in this experiment were $\mathrm{Mg}\left(\mathrm{NO}_{3}\right)_{2} \cdot 6 \mathrm{H}_{2} \mathrm{O}$ (Merck, $\left.256.41 \mathrm{~g} / \mathrm{mol}\right), \mathrm{Ca}\left(\mathrm{NO}_{3}\right)_{2} \cdot 4 \mathrm{H}_{2} \mathrm{O}$ (Merck, $236.15 \mathrm{~g} / \mathrm{mol}$ ), $\quad \mathrm{Al}\left(\mathrm{NO}_{3}\right)_{2} \cdot 9 \mathrm{H}_{2} \mathrm{O}$ (Merck, $375.13 \mathrm{~g} / \mathrm{mol}$ ), $\mathrm{Na}_{2} \mathrm{CO}_{3}$ (Merck, $105.88 \mathrm{~g} / \mathrm{mol}$ ), $\mathrm{NaOH}$ (Merck, $40.00 \mathrm{~g} / \mathrm{mol}$ ), $\mathrm{HCl} 37 \%$ by MallinckrodtAR ${ }^{\oplus}$,
$\mathrm{C}_{2} \mathrm{H}_{5} \mathrm{OH}$ (Avantor, 99\%). Hydrochar prepared from duku peel, anionic dyes direct green (DG), procion red $(\mathrm{PR})$, methyl orange (MO). Water was obtained using a Purite $^{\star}$ water purification system from the Research Center of Inorganic Materials and Complexes.

\section{Instrumentation}

The material characterization was performed using XRD Rigaku mini flex-6000. The concentration of the dye was analyzed using spectrophotometer UV-Visible Biobase BK-UV 1800PC.

\section{Procedure}

\section{Duku peel preparation}

As much as $1 \mathrm{~kg}$ duku peel that has been prepared is washed and cleaned and dried for $3 \mathrm{~h}$ in the sun. The dried duku peel was cut into several pieces and then baked for $8 \mathrm{~h}$ at a temperature of $100{ }^{\circ} \mathrm{C}$. Then the resulting duku peel is left at room temperature, then mashed and filtered with a size of 40 mesh.

\section{Hydrochar preparation}

A total of $2.5 \mathrm{~g}$ of duku peel and $50 \mathrm{~mL}$ of water were put into a $100 \mathrm{~mL}$ Hydrothermal Stainless-steel Autoclave, then baked at $200^{\circ} \mathrm{C}$ for $12 \mathrm{~h}$. After that, the hydrochar was cooled at room temperature and then washed with distilled water. Drying was carried out in an oven at a temperature of $100{ }^{\circ} \mathrm{C}$ for $24 \mathrm{~h}$ to obtain a hydrochar product which was further characterized using FT-IR, XRD, BET, and SEM analysis.

\section{Composite material preparation}

Composite materials were prepared using the coprecipitation method. As much as $100 \mathrm{~mL}$ of $\mathrm{M}^{2+}$ (Ca, $\mathrm{Mg}$, and $\mathrm{Zn}$ ) $0.75 \mathrm{M}$ solution was mixed with $100 \mathrm{~mL}$ of $\mathrm{Al}^{3+} 0.25 \mathrm{M}$ solution. The mixture was stirred for $1 \mathrm{~h}$ and then added $2.5 \mathrm{~g}$ of hydrochar. The mixture was adjusted to $\mathrm{pH} 10$ using $2 \mathrm{M} \mathrm{NaOH}$ to form a gel. Then continued stirring for $10 \mathrm{~h}$ for $\mathrm{MgAl}-\mathrm{HC}\left(85^{\circ} \mathrm{C}\right), 4 \mathrm{~h}$ for $\mathrm{ZnAl}-\mathrm{HC}$ $\left(60^{\circ} \mathrm{C}\right)$, and $6 \mathrm{~h}$ for $\mathrm{CaAl}-\mathrm{HC}\left(85^{\circ} \mathrm{C}\right)$ to form a precipitate. The precipitation obtained was dried at $100^{\circ} \mathrm{C}$ and then characterized using XRD, FT-IR, BET, and SEM.

\section{Adsorption studies}

Adsorption studies were carried out to determine selectivity, regeneration, isotherm, and thermodynamic 
parameters. The selectivity process was carried out by mixing $25 \mathrm{mg} / \mathrm{L}$ of MO (methyl orange), PR (procion red), and DG (direct green) dye as much as $10 \mathrm{~mL}$ each. Then, the dye mixture was adsorbed with $0.02 \mathrm{~g}$ duku peel, $\mathrm{HC}, \mathrm{MgAl}-\mathrm{HC}, \mathrm{CaAl}-\mathrm{HC}$, and $\mathrm{ZnAl}-\mathrm{HC}$ with time variations $(0,30,60,90,120$, and 150) $\mathrm{min}$. After the adsorption process, the separation was carried out to obtain the filtrate. Then a scan was carried out and measured the wavelength using a UV-Vis spectrophotometer. After obtaining a selective dye, proceed to the adsorbent regeneration stage. The regeneration process was carried out to determine the ability of the adsorbent when used repeatedly by adsorption of $1000 \mathrm{mg} / \mathrm{L}$ DG. After the dye is absorbed in the adsorbent, the desorption process is done using ultrasonic water. This adsorption-desorption process is repeated for up to five cycles. Kinetic studies were carried out by varying the time $0,10,30,60,90,120,150$, and $180 \mathrm{~min}$, then measured the absorbance using a UV-Vis spectrophotometer to determine the tendency of the pseudo-first-order (PFO) and pseudo-second-order (PSO) kinetic models. The adsorption isotherm model that has been determined includes Langmuir and Freundlich. The Langmuir isotherm model can determine the parameter $\mathrm{kL}$, which is the adsorption affinity constant $(\mathrm{L} / \mathrm{mg})$, and $\mathrm{Q}_{\max }$, which indicates the adsorption ability of the adsorbent. At the same time, the Freundlich isotherm model can determine the parameter Kf which states the level of adsorption ( $\mathrm{mg} / \mathrm{g}$ ), and $1 / \mathrm{n}$, which is the Freundlich constant which states the heterogeneity factor. While thermodynamics was carried out to determine the adsorption energy, which includes enthalpy $(\Delta \mathrm{H})$, entropy $(\Delta S)$, and Gibbs free energy $(\Delta G)$. A total of $50 \mathrm{~mL}$ of DG $1000 \mathrm{mg} / \mathrm{L}$ was adsorbed using duku peel, $\mathrm{HC}, \mathrm{MgAl}-\mathrm{HC}, \mathrm{CaAl}-\mathrm{HC}$, and $\mathrm{ZnAl}-\mathrm{HC}$ varied the concentration $(50,75,100,125$, and 150) $\mathrm{mg} / \mathrm{L}$ and temperature $(30,40,50 \text {, and } 60)^{\circ} \mathrm{C}$. Then the absorbance was measured using a UV-Vis spectrophotometer.

\section{- RESULTS AND DISCUSSION}

The success of preparing composite materials consisting of layered double hydroxide as a precursor and hydrochar as a support material is proven by characterization data such as XRD, FT-IR, and SEM. Fig. 1(a) presents a peel duku XRD diffractogram with two specific peaks appearing at diffraction angles of $16.9^{\circ}$ and $21.8^{\circ}$. Duku peel treated through hydrothermal carbonization produces HC with almost the same diffraction pattern as Fig. 1(b). XRD characterization was carried out to confirm the presence of typical diffraction peaks of the layered double hydroxide according to JCPDS data No. 87.0493 for Ca/Al, No. 200658 for $\mathrm{Mg} / \mathrm{Al}$ (Balcomb et al. 2015) [14] and No. 48.2023 for $\mathrm{Zn} / \mathrm{Al}$ (Liu et al. 2019) [6]. The diffraction patterns of the MgAl-HC, CaAl-HC, and ZnAl-HC composites are presented in Fig. 1.

Based on Fig. 1, the appearance of the MgAl-HC diffraction peaks at $11.47^{\circ}(003), 22.86^{\circ}(006)$, $61.62^{\circ}(113), 65.50^{\circ}(116)$ has been confirmed as typical diffraction peaks of layered double hydroxide. These data follow JCPDS 20-0658, where the LDH diffraction peaks are around $11.8^{\circ}(003), 62.3^{\circ}(113)$, and $66.3^{\circ}(116)$. In addition, there is a confirmed diffraction peak of $\mathrm{HC}$ around 22 (002), which indicates the characteristics of cellulose (Castro et al thermal decomposition). The diffraction of the CaAl-HC composite (Fig. 1(b)) at $10.16^{\circ}(003), 18.0^{\circ}(002)$, and $20.25^{\circ}(006)$ confirmed the diffraction of the layered double hydroxide according to JCPDS No. 87-0493. Fig. 1 shows the diffraction of $\mathrm{ZnAl}-\mathrm{HC}$ at $10.05^{\circ}(003), 19.92^{\circ}(002), 34.10^{\circ}(006)$, and

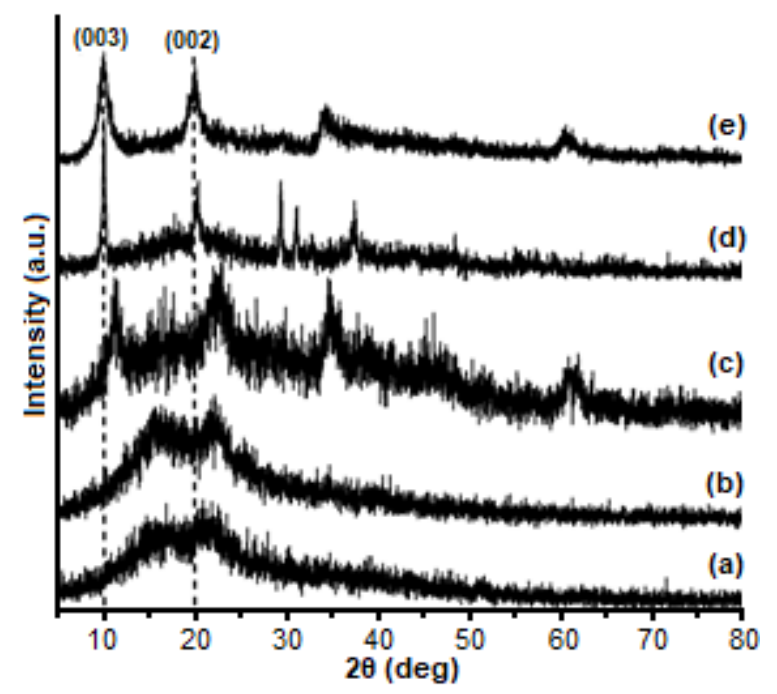

Fig 1. Diffraction pattern of (a) duku peel, (b) HC, (c) MgAl-HC, (d) CaAl-HC, and (e) ZnAl-HC 
$60.22^{\circ}(110)$. Based on JCPDS data No. 48.2023 confirmed the successful preparation of $\mathrm{ZnAl}-\mathrm{HC}$ composites. The diffraction pattern in Fig. 1 shows the presence of diffraction at $2 \theta$ around $19^{\circ}$, approved as a diffraction peak from hydrochar. Based on these data, the preparation of composite material in the form of $\mathrm{Zn} / \mathrm{Al}$ Hc has been successfully carried out, judging from the diffraction peaks of the supporting material, which are within the characteristics of the composite.

The success of composite preparation using $\mathrm{HC}$ is also supported by the FT-IR analysis presented in Fig. 2. The composite spectra of MgAl-HC, CaAl-HC, and $\mathrm{ZnAl}-\mathrm{HC}$ have the characteristics of $\mathrm{HC}$ found at 3425 and $1627 \mathrm{~cm}^{-1}$ which were confirmed as vibrations of the hydroxyl and carbonyl OH groups [15]. There is also a C$\mathrm{H}$ vibration of the cellulose at $2931 \mathrm{~cm}^{-1}$ [16]. The primary amide content in the duku peel indicated the presence of a $\mathrm{C}=\mathrm{O}$ group seen at $1635 \mathrm{~cm}^{-1}$. Another vibration at 1442 $\mathrm{cm}^{-1}$ revealed the $\mathrm{C}=\mathrm{C}$ strain of the aromatic compounds, and there is a characteristic vibration of the layered double hydroxide (M-O), which is below $1000 \mathrm{~cm}^{-1}$.

Determine the morphological characteristics of the material conducted by SEM analysis. The SEM's characterization results presented in Fig. 3 show the morphology of the duku peel adsorbent particles, which tend to agglomerate in the same phase or are commonly referred to as aggregation. While Fig. 3(b) shows the particle morphology pattern of the hydrochar adsorbent at a temperature of $200{ }^{\circ} \mathrm{C}$, which tends to be heterogeneous and has an irregular shape, this is due to the hydrothermal carbonization treatment given, causing the particles to undergo splitting or commonly referred to as deaggregation. The morphology of MgAl$\mathrm{HC}$ in Fig. 3(c) shows the presence of agglomerates with large and irregular pore sizes. While $\mathrm{CaAl}-\mathrm{HC}$ has a small pore size with a smooth surface. On the other hand, $\mathrm{ZnAl}-\mathrm{HC}$ has a heterogeneous pore size, with a lower agglomeration rate than $\mathrm{MgAl}-\mathrm{HC}$.

The large surface area is one of the advantages of the prepared composite material. The characterization evidences the increase in surface area in $\mathrm{N}_{2}$ adsorptiondesorption, whose profile can be seen in Fig. 4 and Table 1.

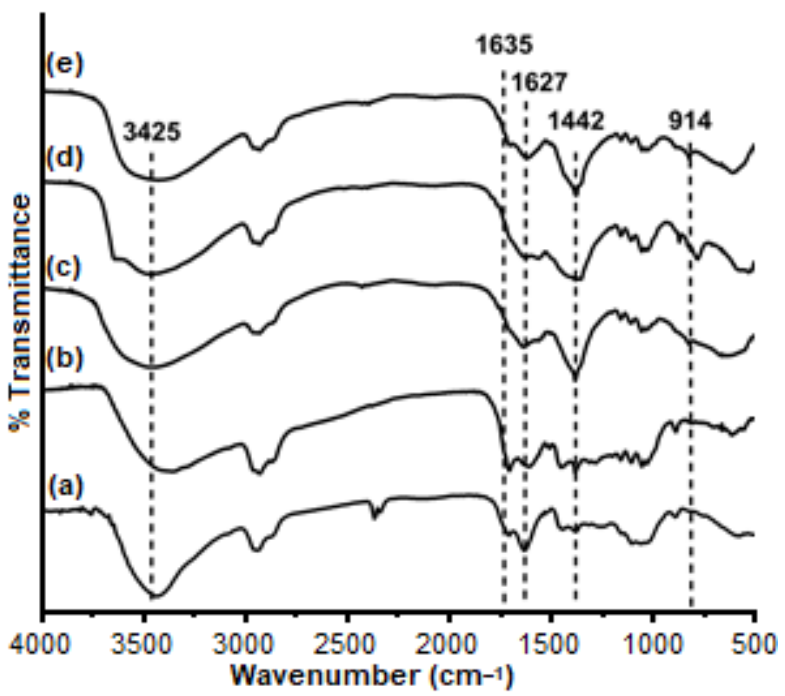

Fig 2. FT-IR spectra of (a) duku peel, (b) HC, composite materials (c) MgAl-HC, (d) CaAl-HC, dan (e) ZnAl-HC

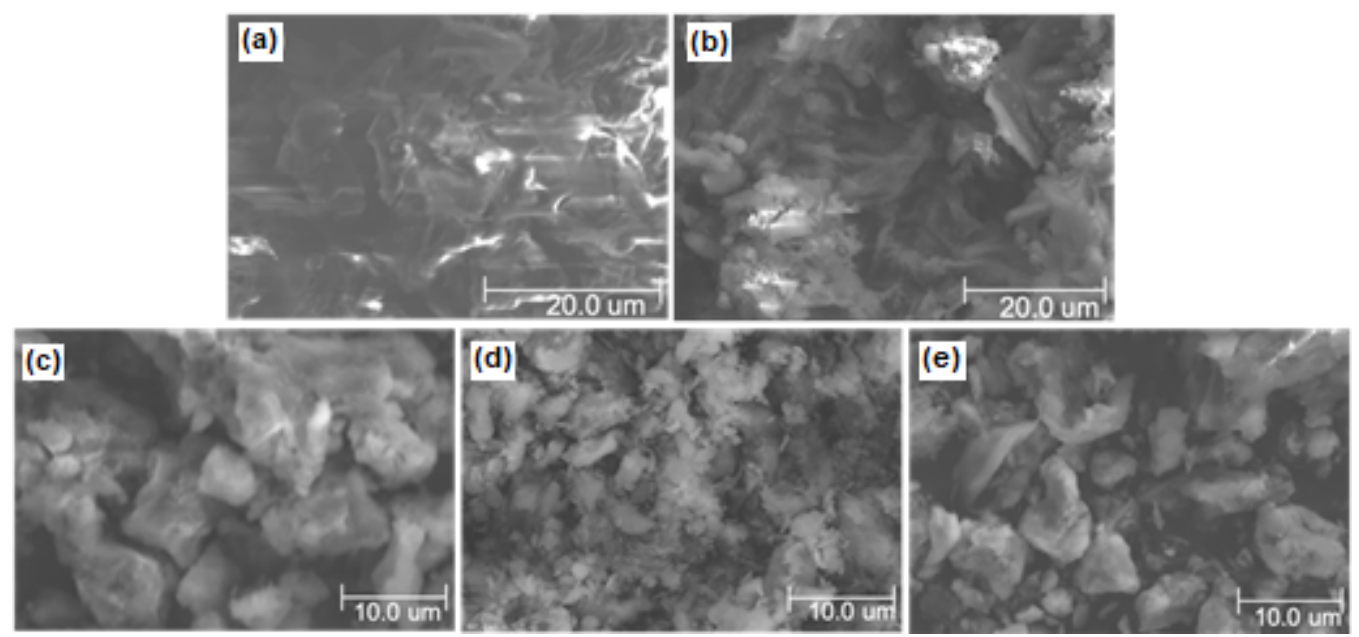

Fig 3. Surface morphology of (a) duku peel, (b) HC, (c) MgAl-HC, (d) CaAl-HC, and (e) ZnAl-HC 


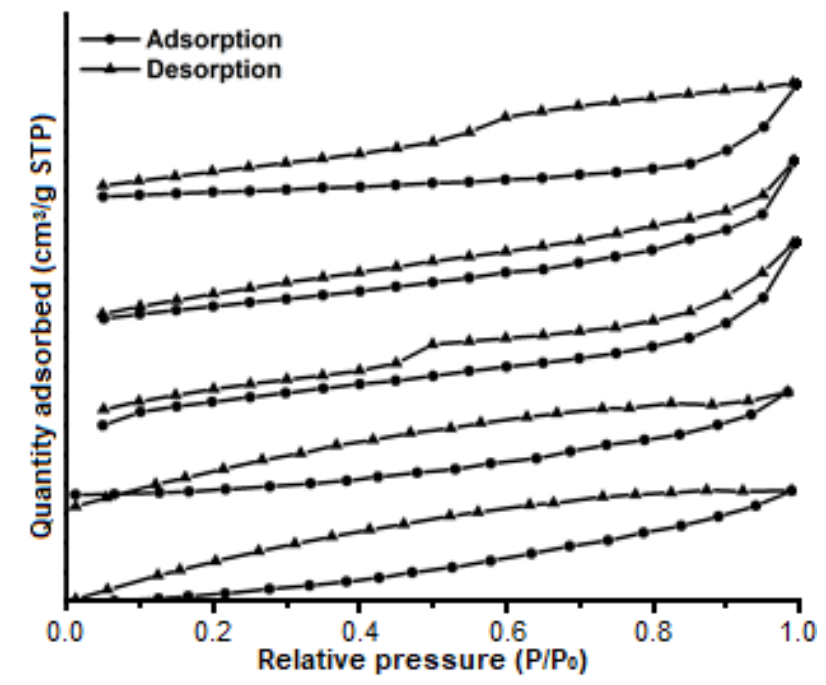

Fig 4. $\mathrm{N}_{2}$ Adsorption-desorption profile of (a) duku peel, (b) HC, (c) MgAl-HC, (d) CaAl-HC, and (e) ZnAl-HC

Table 1. BET surface area analysis

\begin{tabular}{lccc}
\hline Material & $\begin{array}{c}\text { Surface area } \\
\left(\mathrm{m}^{2} / \mathrm{g}\right)\end{array}$ & $\begin{array}{c}\text { Pore volume } \\
\left(\mathrm{cm}^{3} / \mathrm{g}\right)\end{array}$ & $\begin{array}{c}\text { Pore diameter } \\
(\mathrm{nm})\end{array}$ \\
\hline Duku peel & 12.34 & 0.02 & 2.65 \\
HC & 22.63 & 0.04 & 2.77 \\
MgAl-HC & 11.84 & 0.03 & 17.06 \\
CaAl-HC & 74.21 & 0.15 & 19.10 \\
ZnAl-HC & 29.87 & 0.04 & 24.42 \\
\hline
\end{tabular}

The $\mathrm{N}_{2}$ adsorption-desorption process produces a profile that describes the pore of the material. Fig. 4 shows the change in profile shape from LDH to composite.

According to Alsamman [17], the isotherm pattern (Fig. 4) of duku peel, HC, and composites (MgAl-HC, $\mathrm{CaAl}-\mathrm{HC}$, and $\mathrm{ZnAl}-\mathrm{HC}$ ) resembled type IV. The type IV isotherm pattern indicates a mesoporous material that shows non-overlapping adsorption and desorption patterns. The adsorption-desorption profile of $\mathrm{N}_{2}$ on $\mathrm{MgAl}-\mathrm{HC}, \mathrm{CaAl}-\mathrm{HC}$, and ZnAl-HC composites stated the occurrence of $\mathrm{H} 4$ hysteresis. The hysteresis occurs in the adsorption-desorption process with a different mechanism on the adsorbent with pores that form gaps and is indicated by the adsorbent having a mesoporous size.

The surface area of $\mathrm{MgAl}-\mathrm{HC}$ is $11.84 \mathrm{~m}^{2} / \mathrm{g}$, $\mathrm{CaAl} / \mathrm{Hc}$ is $74.21 \mathrm{~m}^{2} / \mathrm{g}$, and $\mathrm{ZnAl}-\mathrm{HC}$ is $29.87 \mathrm{~m}^{2} / \mathrm{g}$. Based on the data in Table 1, the value of the pore volume is proportional to the surface area. The large surface area results in a comparable pore volume. The pore diameter size shows a tendency inversely proportional to the surface area and pore volume values. The increase in surface area and the pore volume is inversely proportional to the small pore diameter size.

Based on the described characterization data, MgAl-HC, CaAl-HC, ZnAl-HC composites have been successfully prepared as adsorbents. Proving the ability of MgAl-HC, CaAl-HC, ZnAl-HC composites was determined through several parameters. The determination of selectivity is the first parameter that is carried out to see the ability of the adsorbent in the adsorption of mixed dyes. The adsorption process carried out selectivity on mixed dyes consisting of PR, $\mathrm{MO}$, and DG. Results of the selectivity process presented in Fig. 5 show the change in absorbance before and after the adsorption process to the effect of time. Overall, the absorbance decreased with increasing time.

The spectrum in Fig. 5 shows that PR is at $544 \mathrm{~nm}$, MO is $504 \mathrm{~nm}$, and DG is at $623 \mathrm{~nm}$. Before the adsorption process occurs, each dye is mixed with the same concentration, $25 \mathrm{mg} / \mathrm{g}$. The adsorption process of mixed dyes was carried out with time variations of 0,30 , $60,90,120$, and $150 \mathrm{~min}$. After the adsorption process was carried out, there was a decrease in the concentration of each dye. The decrease in concentration in $\mathrm{MO}$ reached $12.49 \mathrm{mg} / \mathrm{g}$ in duku peel, $12.05 \mathrm{mg} / \mathrm{g}$ in $\mathrm{HC}, 0.558 \mathrm{in}$ $\mathrm{MgAl} / \mathrm{HC}, 3.32 \mathrm{mg} / \mathrm{g}$ in $\mathrm{CaAl} / \mathrm{HC}$, and $9.95 \mathrm{mg} / \mathrm{g}$ in $\mathrm{ZnAl} / \mathrm{HC}$. The decrease in concentration in $\mathrm{PR}$ reached $7.94 \mathrm{mg} / \mathrm{g}$ in duku peel, $8.77 \mathrm{mg} / \mathrm{g}$ in $\mathrm{HC}, 7.40 \mathrm{mg} / \mathrm{g}$ in $\mathrm{MgAl} / \mathrm{HC}, 7.23 \mathrm{mg} / \mathrm{g}$ in $\mathrm{CaAl} / \mathrm{HC}$, and $7.22 \mathrm{mg} / \mathrm{g}$ in $\mathrm{ZnAl} / \mathrm{HC}$. While the spectrum in Fig. 5 shows a decrease in concentration in DG reaching $23.32 \mathrm{mg} / \mathrm{g}$ in duku peel, 10.65 in $\mathrm{HC}, 0.32 \mathrm{mg} / \mathrm{g}$ in $\mathrm{MgAl} / \mathrm{HC}, 0.76 \mathrm{mg} / \mathrm{g}$ in $\mathrm{CaAl} / \mathrm{HC}$, and $1.26 \mathrm{mg} / \mathrm{g}$ in $\mathrm{ZnAl} / \mathrm{HC}$. Based on these data, DG showed a significant decrease compared to MO and PR. The duku peel adsorbents, $\mathrm{HC}, \mathrm{MgAl}-\mathrm{HC}$, CaAl-HC, and ZnAl-HC, showed a selective adsorption tendency towards DG. Based on these results, the next adsorption process was carried out with a DG selective dye.

Furthermore, the regeneration process is carried out to determine the ability of the adsorbent during 

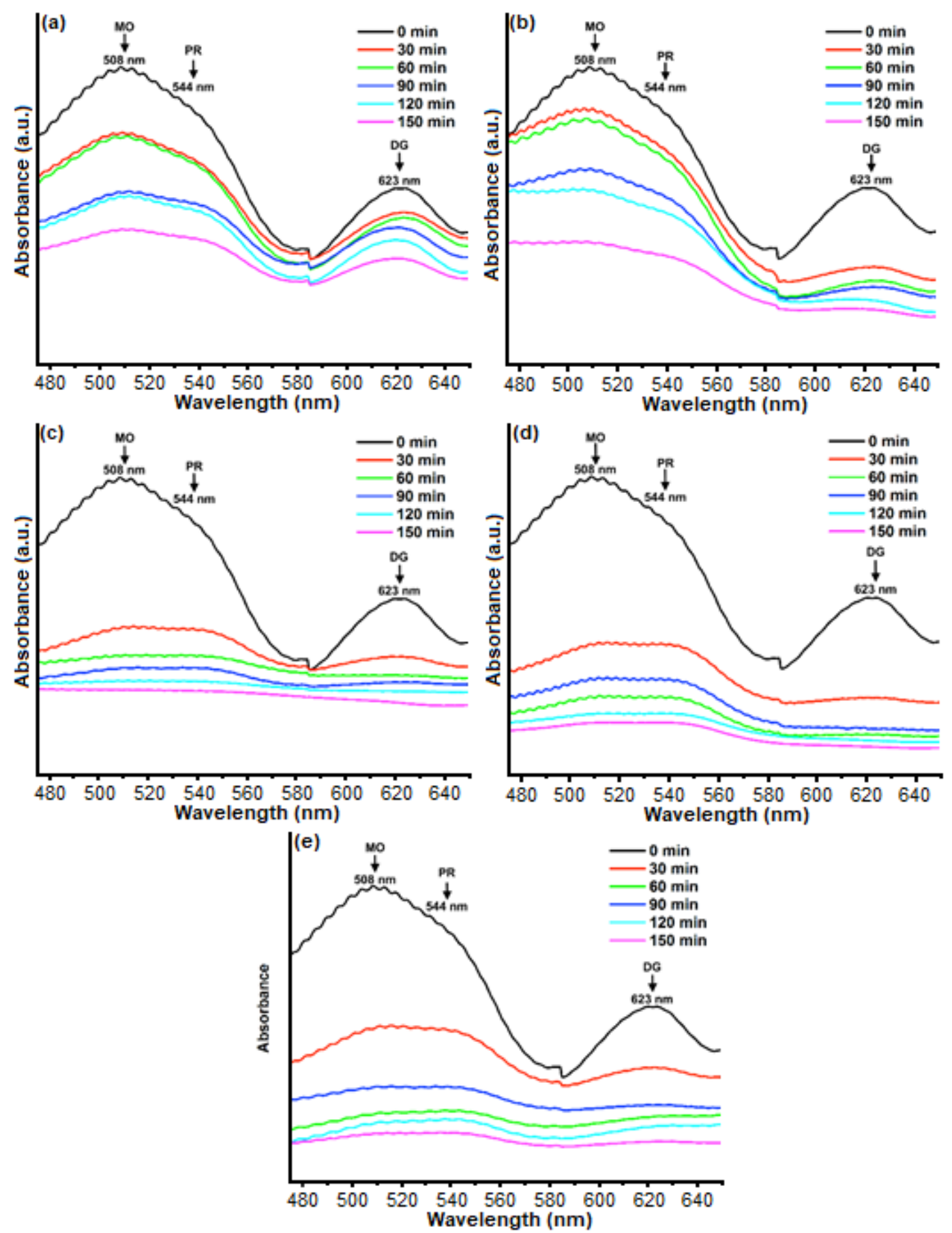

Fig 5. UV-Visible spectra of mixture anionic dyes (PR, MO, and DG) using (a) duku peel, (b) HC, (c) MgAl-HC, (d) CaAl-HC, dan (e) ZnAl-HC

repeated use. The duku peel regeneration process results, $\mathrm{HC}, \mathrm{MgAl}-\mathrm{HC}$, CaAl-HC, and $\mathrm{ZnAl}-\mathrm{HC}$, are presented in Fig. 6. duku peel and HC show a decrease in the adsorption ability of the regeneration product. The first cycle of duku peel was $54.54 \%$ which decreased to $2.04 \%$ in the last cycle. The regeneration results on HC showed a more excellent value than duku peel. The first cycle showed an HC adsorption ability of $70.31 \%$, but its ability also decreased to $8.41 \%$ at the last cycle.

The results of composite regeneration showed a 


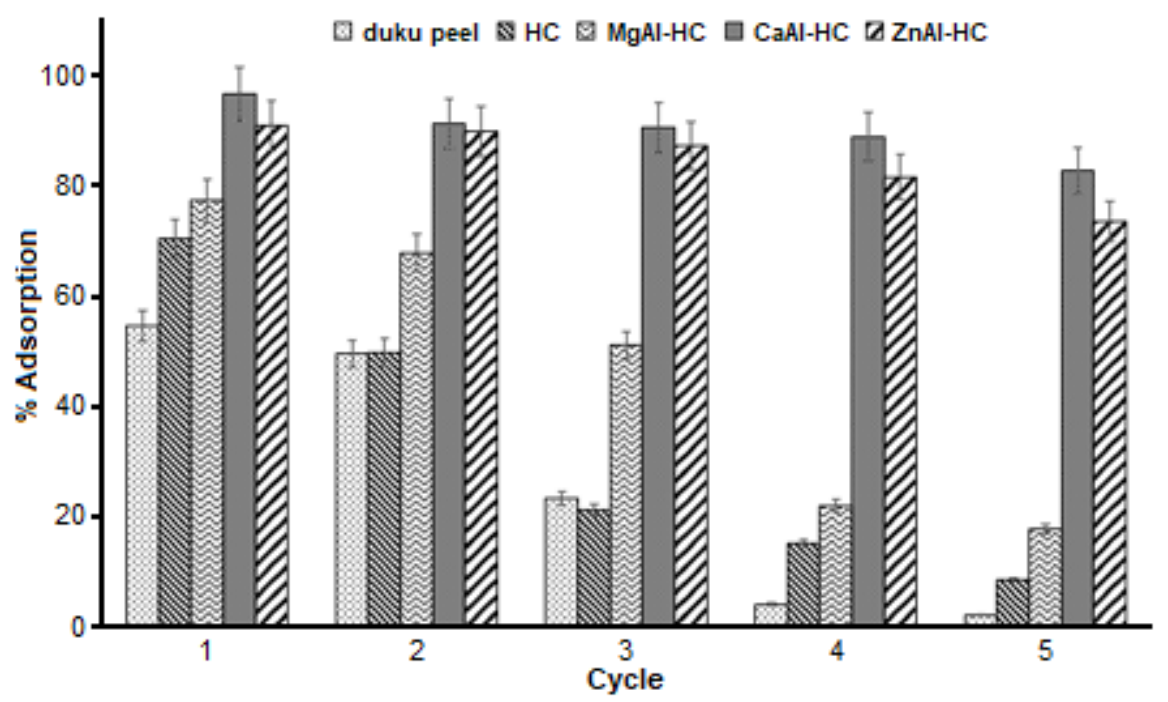

Fig 6. Regeneration process of duku peel, $\mathrm{HC}, \mathrm{MgAl}-\mathrm{HC}$, CaAl-HC, and $\mathrm{ZnAl}-\mathrm{HC}$

stable curve, where the change in adsorption ability was not so significant from the first to the last cycle. The first cycle in MgAl-HC reached $77.27 \%$, then became $51.02 \%$ in the third cycle to $17.57 \%$ in the previous cycle. CaAlHC showed the first regeneration yield of $96.66 \%$ and remained $90.555 \%$ in the third cycle until it decreased to $82.70 \%$ in the last cycle. $\mathrm{ZnAl}-\mathrm{HC}$ regeneration in the first cycle reached $90.91 \%$ and fell to $73.52 \%$ in the previous cycle. Based on these data, CaAl-HC achieved the best regeneration ability compared to $\mathrm{MgAl}-\mathrm{HC}$ and $\mathrm{ZnAl}-\mathrm{HC}$.

The adsorption ability of MgAl-HC, CaAl-HC, ZnAl-HC composite adsorbents was determined by isotherm parameters which can be seen in Table 2. $\mathrm{Q}_{\max }$ in Table 2 shows the $\mathrm{Q}_{\max }$ that the adsorbent can do. MgAl$\mathrm{HC}$, CaAl-HC, and ZnAl-HC composites showed a higher $\mathrm{Q}_{\max }$ than duku peel and HC. The $\mathrm{Q}_{\max }$ of MgAl-HC, CaAl-HC, and ZnAl-HC composites, respectively 94.34 $\mathrm{mg} / \mathrm{g}, 128.20 \mathrm{mg} / \mathrm{g}$, and $89.28 \mathrm{mg} / \mathrm{g}$, show that CaAl-HC has the best ability in the DG adsorption process. The ability of CaAl-HC is supported by surface area data from
CaAl-HC in Table 1, which has the largest surface area compared to MgAl-HC and $\mathrm{ZnAl}-\mathrm{HC}$, where surface area is one of the parameters that most affect the adsorption capacity of the adsorbent. Several other studies have also carried out the adsorption process on DG, the results of which are presented in Table 3.

In addition to the $\mathrm{Q}_{\max }$ value, Table 2 also shows the trend of the Langmuir and Freundlich isotherm models. The isotherm model is determined based on the linear regression value $\left(\mathrm{R}^{2}\right)$ closer to 1 . Table 2 shows that the MgAl-HC, $\mathrm{CaAl}-\mathrm{HC}$, and $\mathrm{ZnAl}-\mathrm{HC}$ composites have an $\mathrm{R}^{2}$ value in the Langmuir isotherm model, which is more dominant close to 1 than the Freundlich isotherm model. Based on these data, the DG adsorption process using MgAl-HC, CaAl-HC, and ZnAl-HC occurs monolayer. Furthermore, determine the thermodynamic parameters consisting of Gibbs free energy $(\Delta G)$, enthalpy $(\Delta H)$, and entropy $(\Delta S)$ which are presented in Table 3. Overall, $\Delta \mathrm{G}$ in Table 3 shows negative values.

Table 2. Isotherm parameters

\begin{tabular}{lcccccc}
\hline \multirow{2}{*}{ Materials } & \multicolumn{3}{c}{ Langmuir } & \multicolumn{3}{c}{ Freundlich } \\
\cline { 2 - 7 } & $\mathrm{k}_{\mathrm{L}}$ & $\mathrm{Q}_{\max }(\mathrm{mg} / \mathrm{g})$ & $\mathrm{R}^{2}$ & $\mathrm{k}_{\mathrm{F}}$ & $1 / \mathrm{n}$ & $\mathrm{R}^{2}$ \\
\hline Duku peel & 0.76 & 46.99 & 0.99 & 1.36 & 0.61 & 0.97 \\
$\mathrm{HC}$ & 0.10 & 48.78 & 0.98 & 11.26 & 0.84 & 0.98 \\
MgAl-HC & 1.12 & 94.34 & 0.99 & 1.09 & 0.52 & 0.96 \\
CaAl-HC & 0.09 & 128.20 & 0.96 & 4.99 & 1.20 & 0.69 \\
ZnAl-HC & 0.04 & 89.29 & 0.91 & 2.56 & 0.91 & 0.64 \\
\hline
\end{tabular}


Table 3. Thermodynamic parameters

\begin{tabular}{|c|c|c|c|c|}
\hline Adsorbent & $\mathrm{T}(\mathrm{K})$ & $\Delta \mathrm{H}(\mathrm{kJ} / \mathrm{mol})$ & $\Delta \mathrm{S}(\mathrm{J} / \mathrm{mol} . \mathrm{K})$ & $\Delta \mathrm{G}(\mathrm{kJ} / \mathrm{mol})$ \\
\hline \multirow{4}{*}{ Duku peel } & 303 & \multirow{4}{*}{41.75} & 0.14 & -0.34 \\
\hline & 313 & & & -1.73 \\
\hline & 323 & & & -3.12 \\
\hline & 333 & & & -4.51 \\
\hline \multirow{4}{*}{$\mathrm{Hc}$} & 303 & \multirow{4}{*}{20.13} & 0.07 & -0.83 \\
\hline & 313 & & & -1.52 \\
\hline & 323 & & & -2.21 \\
\hline & 333 & & & -2.91 \\
\hline \multirow{4}{*}{ MgAl-Hc } & 303 & \multirow{4}{*}{20.68} & 0.07 & 0.78 \\
\hline & 313 & & & 0.13 \\
\hline & 323 & & & -0.53 \\
\hline & 333 & & & -1.19 \\
\hline \multirow{4}{*}{$\mathrm{CaAl}-\mathrm{Hc}$} & 303 & \multirow{4}{*}{26.13} & 0.09 & -1.12 \\
\hline & 313 & & & -2.02 \\
\hline & 323 & & & -2.92 \\
\hline & 333 & & & -3.82 \\
\hline \multirow{4}{*}{$\mathrm{ZnAl-Hc}$} & 303 & \multirow{4}{*}{65.65} & 0.22 & -0.48 \\
\hline & 313 & & & -2.67 \\
\hline & 323 & & & -4.85 \\
\hline & 333 & & & -7.03 \\
\hline
\end{tabular}

According to Siregar et al., a negative $\Delta \mathrm{G}$ delta value indicates a spontaneous adsorption process [18]. The positive enthalpy in Table 3 shows the adsorption process that takes place endothermic. The enthalpy value in the 20.13-65.65 kJ/mol range indicates the physical and chemical adsorption process. According to Ngah et al., the range of enthalpy values at $40-120 \mathrm{~kJ} / \mathrm{mol}$ is a chemisorption process [19]. However, if the enthalpy has a value below that range, the adsorption process takes place physisorption [20]. The entropy value, which tends to be minor, close to zero, indicates increased randomness at the solid/solution interface [21]. Table 4 present the adsorption capacity of several adsorbents for DG.

The Van't Hoff equation is used to determine the change in the equilibrium constant concerning temperature variations (Fig. 7). Based on some literature, the Van't Hoff equation in linear form is most widely used by applying $\mathrm{Ln}$.

$\ln K_{e}^{\circ}=\frac{\Delta S^{\circ}}{R}-\left(\frac{\Delta H^{\circ}}{R}\right) \frac{1}{T}$

The equation is used to calculate the entropy and enthalpy changes in the adsorption process, where the Ke
Table 4. comparison of sorption capacities of various adsorbents for DG, MO, and PR

\begin{tabular}{lcc}
\hline Adsorbent & $\begin{array}{c}\text { Maximum Capacity } \\
\left(\mathrm{mg}^{-\mathrm{g}^{-1}}\right)\end{array}$ & Ref \\
\hline ZFN-CTAB & 64.10 & {$[22]$} \\
Cationized sawdust & 35.70 & {$[23]$} \\
Natural sawdust & 9.30 & {$[23]$} \\
Biochar-CMC & 39.47 & {$[24]$} \\
$\mathrm{Fe}_{3} \mathrm{O}_{4} @ \mathrm{C}$ & 38.03 & {$[25]$} \\
$\mathrm{CoAl}-\mathrm{LDH}$ & 32.27 & {$[26]$} \\
Magnetic geopolymer & 25.46 & {$[27]$} \\
Corncob & 2.86 & {$[28]$} \\
Duku peel & 46.99 & \\
$\mathrm{HC}$ & 48.78 & \\
MgAl-HC & 94.34 & This work \\
CaAl-HC & 128.20 & \\
ZnAl-HC & 89.28 & \\
\hline
\end{tabular}

constant is obtained from the adsorption isotherm.

The kinetic parameters determined in the DG adsorption process using duku peel, $\mathrm{HC}, \mathrm{MgAl}-\mathrm{HC}$, $\mathrm{CaAl}-\mathrm{HC}$, and ZnAl-HC include pseudo-first-order (PFO) and pseudo-second-order (PSO). Determination 

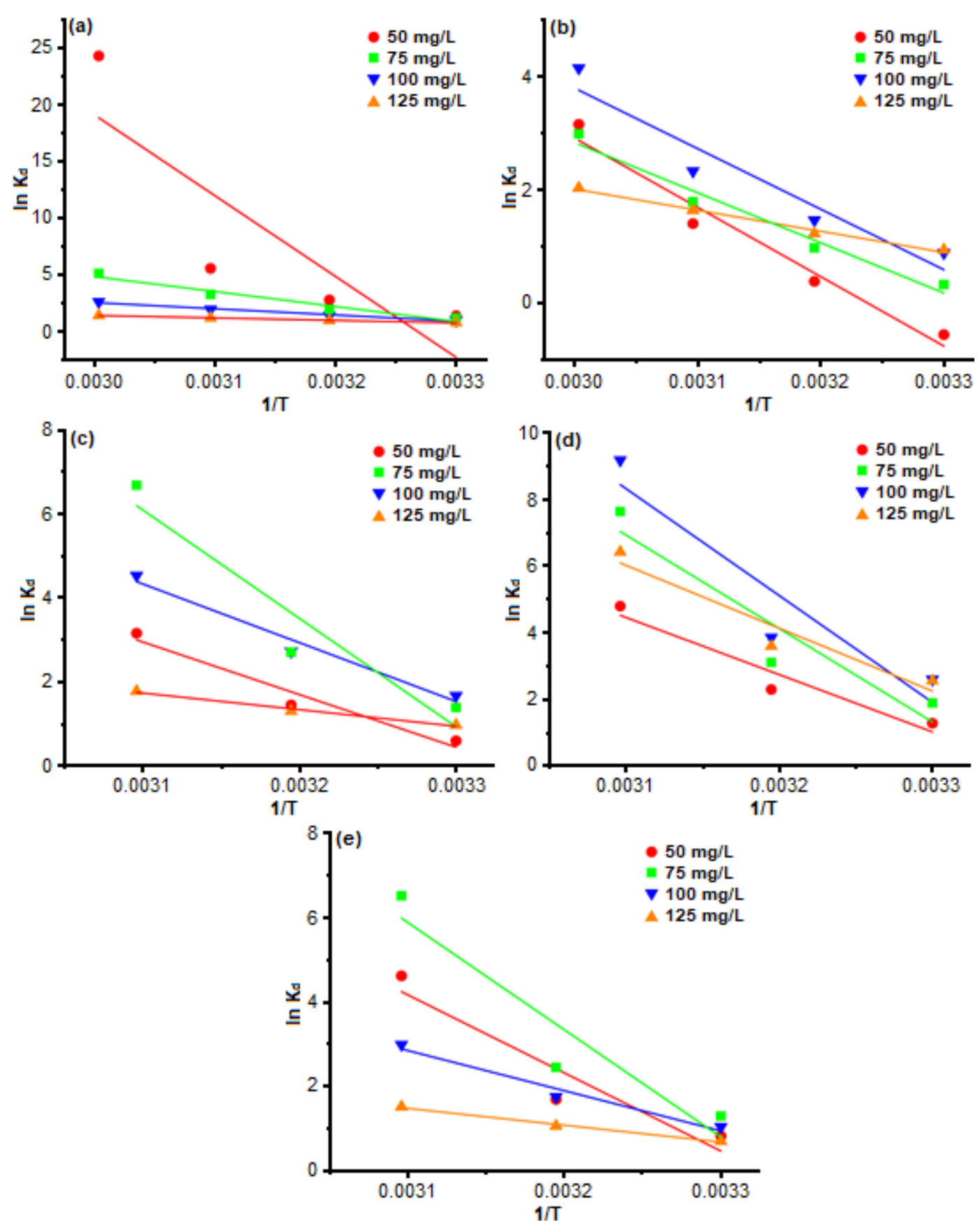

Fig 7. Van't Hoff linear plot for DG adsorption on (a) duku peel, (b) HC, (c) MgAl-HC, (d) CaAl-HC, and (e) ZnAl-HC

of kinetic parameters is done by varying the adsorption contact time from $0-150 \mathrm{~min}$, presented in Fig. 8. Variations in contact time are carried out until the adsorption process reaches equilibrium time. Overall, the DG adsorption process got an equilibrium time of $90 \mathrm{~min}$, indicating that the adsorption process after that minute has been saturated.

In addition, variations in adsorption time are also used to determine the adsorption kinetics model, which is presented in Table 5. The PFO kinetics model explains that the adsorption process is influenced by one of the components between the adsorbent or only the adsorbate. The PSO kinetic model demonstrates that the adsorption process occurs under the influence of both the adsorbent and the adsorbate components. The linear regression value $\left(\mathrm{R}^{2}\right)$, which tends to be closer to 1 , as 

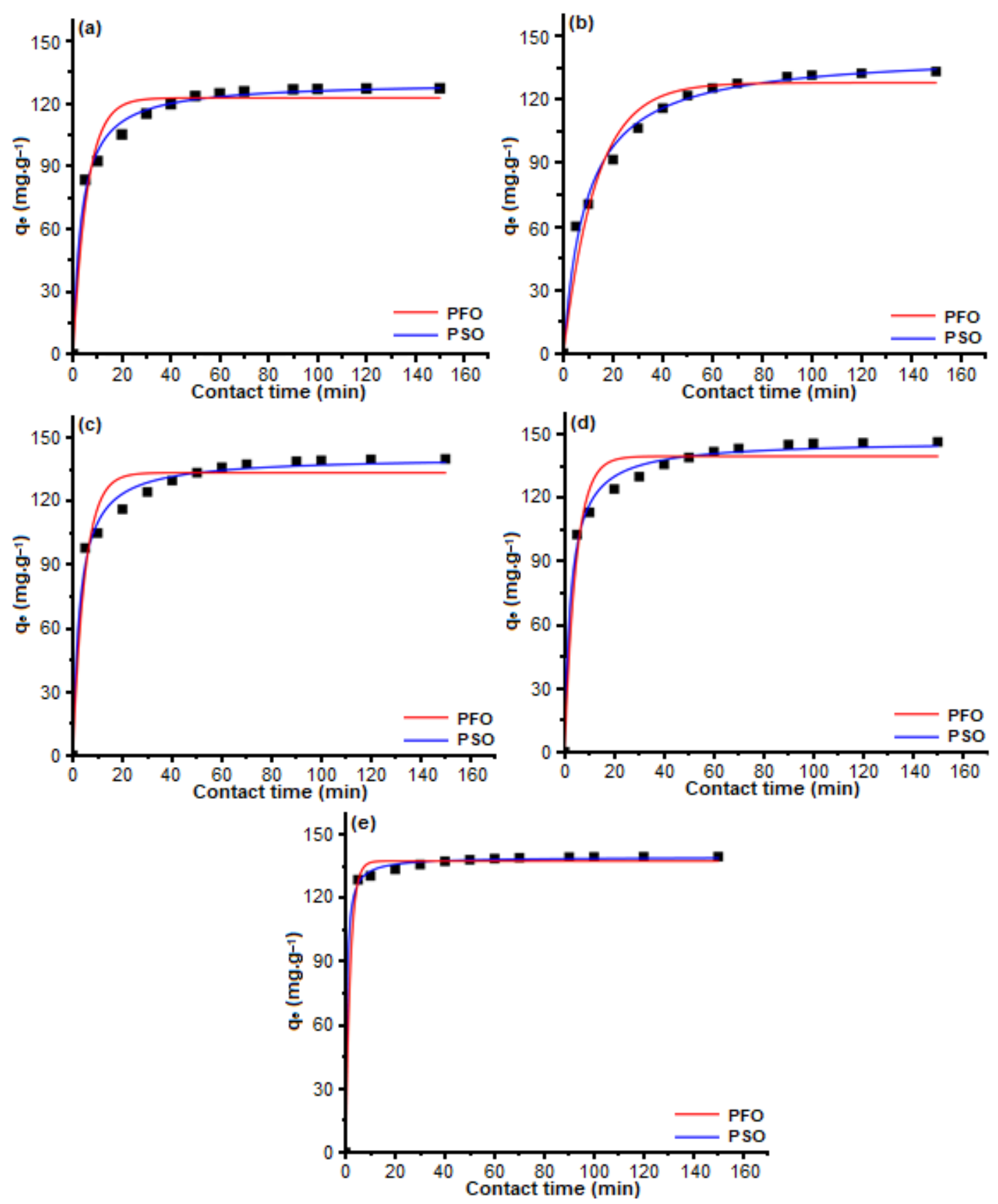

Fig 8. Variations in adsorption time of DG on (a) duku peel, (b) HC, (c) MgAl-HC, (d) CaAl-HC, dan (e) ZnAl-HC

Table 5. Adsorption kinetic models of DG on duku peel, HC, MgAl-HC, CaAl-HC, and ZnAl-HC

\begin{tabular}{lccccccc}
\hline \multirow{2}{*}{ Adsorbent } & \multirow{2}{*}{$\mathrm{Qe}_{\text {exp }}(\mathrm{mg} / \mathrm{g})$} & \multicolumn{3}{c}{$\mathrm{PFO}$} & \multicolumn{3}{c}{$\mathrm{PSO}$} \\
\cline { 3 - 8 } & $\mathrm{Qe}_{\text {Calc }}(\mathrm{mg} / \mathrm{g})$ & $\mathrm{R}^{2}$ & $\mathrm{k}_{1}$ & $\mathrm{Qe}_{\text {Calc }}(\mathrm{mg} / \mathrm{g})$ & $\mathrm{R}^{2}$ & $\mathrm{k}_{2}$ \\
\hline Duku peel & 127.22 & 69.21 & 0.99 & 0.05 & 131.58 & 0.99 & 0.002 \\
$\mathrm{HC}$ & 133.13 & 96.94 & 0.99 & 0.04 & 142.86 & 0.99 & 0.0007 \\
MgAl-HC & 139.96 & 70.39 & 0.98 & 0.05 & 144.93 & 0.99 & 0.001 \\
CaAl-HC & 146.39 & 67.20 & 0.97 & 0.04 & 149.25 & 0.99 & 0.001 \\
ZnAl-HC & 139.50 & 24.02 & 0.92 & 0.05 & 140.84 & 0.99 & 0.008 \\
\hline
\end{tabular}


shown in Table 5, determined the adsorption kinetics model.

In addition, variations in adsorption time are also used to determine the adsorption kinetics model, which is presented in Table 5. The PFO kinetics model explains that the adsorption process is influenced by one of the components between the adsorbent or only the adsorbate. The PSO kinetic model demonstrates that the adsorption process occurs under the influence of both the adsorbent and the adsorbate components. The linear regression value $\left(R^{2}\right)$, which tends to be closer to 1 , as shown in Table 5 , determined the adsorption kinetics model.

Duku peel shows the tendency of the PSO kinetic model as seen from the $\mathrm{R}^{2}$ value in the kinetic model, which is closer to 1 . The same thing also happened to the DG adsorption process using $\mathrm{HC}, \mathrm{MgAl}-\mathrm{HC}, \mathrm{CaAl}-\mathrm{HC}$, and $\mathrm{ZnAl}-\mathrm{HC}$. The $\mathrm{R}^{2}$ value from Table 5 of the adsorbent shows a tendency to the PSO kinetic model so that the overall adsorption process tends to follow the PSO kinetic model.

\section{- CONCLUSION}

Composite materials have proven adsorption capabilities, as evidenced by the $\mathrm{Q}_{\max }$ value. CaAl-HC has the highest $\mathrm{Q}_{\max }$ among other composites, which reach $128.205 \mathrm{mg} / \mathrm{g}$, while $\mathrm{MgAl}-\mathrm{HC}$ has a $\mathrm{Q}_{\max }$ of $94.34 \mathrm{mg} / \mathrm{g}$ and ZnAl-HC $89.286 \mathrm{mg} / \mathrm{g}$. The adsorption ability of $\mathrm{CaAl}-\mathrm{HC}$ was also proven by the regeneration process which lasted until the fifth cycle. The first cycle in the regeneration process showed $96.658 \%$ and in the last cycle 82.697\%. This shows that CaAl-HC has potential as a superior adsorbent with good adsorption ability and is effective for regeneration.

\section{- ACKNOWLEDGMENTS}

We wish to express our gratitude to the research center Inorganic Materials and Complexes, Sriwijaya University, for instrument analysis.

\section{- REFERENCES}

[1] Behbahani, E.S., Dashtian, K., and Ghaedi, M., 2020, $\mathrm{Fe} / \mathrm{Co}$-chalcogenide-stabilized $\mathrm{Fe}_{3} \mathrm{O}_{4}$ nanoparticles supported MgAl-layered double hydroxide as a new magnetically separable sorbent for the simultaneous spectrophotometric determination of anionic dyes, Microchem. J., 152, 104431.

[2] Starukh, H., and Levytska, S., 2019, The simultaneous anionic and cationic dyes removal with $\mathrm{Zn}$ e Al layered double hydroxides, Appl. Clay Sci., 180, 105183.

[3] Lim, S.J., and Kim, T.H., 2015, Combined treatment of swine wastewater by electron beam irradiation and ion-exchange biological reactor system, Sep. Purif. Technol., 146, 42-49.

[4] Zhuang, H., Han, H., Ma, W., Hou, B., Jia, S., and Zhao, Q., 2015, Advanced treatment of biologically pretreated coal gasification wastewater by a novel heterogeneous Fenton oxidation process, $J$. Environ. Sci., 33, 12-20.

[5] Mólgora, C.C., Domínguez, A.M., Avila, E.M., Drogui, P., and Buelna, G., 2013, Removal of arsenic from drinking water: A comparative study between electrocoagulation-microfiltration and chemical coagulation-microfiltration processes, Sep. Purif. Technol., 118, 645-651.

[6] Liu, H., Zhou, H., Li, H., Liu, X., Ren, C., Liu, Y., Li, W., and Zhang, M., 2019, Fabrication of $\mathrm{Bi}_{2} \mathrm{~S}_{3} @ \mathrm{Bi}_{2} \mathrm{WO}_{6} / \mathrm{WO}_{3}$ ternary photocatalyst with enhanced photocatalytic performance: Synergistic effect of Z-scheme/traditional heterojunction and oxygen vacancy, J. Taiwan Inst. Chem. Eng., 95, 94102.

[7] Liu, X., Zhou, Z., Yin, J., He, C., Zhao, W., and Zhao, C., 2020, Fast and environmental-friendly approach towards uniform hydrogel particles with ultrahigh and selective removal of anionic dyes, $J$. Environ. Chem. Eng., 8 (5), 104352.

[8] Milagres, J.L., Bellato, C.R., Ferreira, S.O., de M. Guimarães, L., de P. Tonon, G.J., and Bolandini, A., 2019, Simultaneous removal process of divalent metal and anionic and cationic dyes by layered reconstruction with hydrocalumite intercalated with dodecyl sulfate, Colloids Surf., A, 582, 123890.

[9] Meng, Z., Wu, M., Zhao, S., Jing, R., Li, S., Shao, Y., Liu, X., Lv, F., Liu, A., and Zhang, Q., 2019, Removing anionic dyes from wastewater based on in-situ formation of $\mathrm{Fe}_{3} \mathrm{O}_{4} @ \mathrm{Zn}$ - $\mathrm{Al}$ layered double 
hydroxides by self-assembly, Appl. Clay Sci., 170, 4145.

[10] Li, N., Chang, Z., Dang, H., Zhan, Y., Lou, J., Wang, S., Attique, S., Li, W., Zhou, H., and Sun, C., 2020, Deep eutectic solvents assisted synthesis of $\mathrm{MgAl}$ layered double hydroxide with enhanced adsorption toward anionic dyes, Colloids Surf., A, 591, 124507.

[11] Daud, M., Hai, A., Banat, F., Wazir, M.B., Habib, M., Bharath, G., and Al-Harthi, M.A., 2019, A review on the recent advances, challenges and future aspect of layered double hydroxides (LDH) - Containing hybrids as promising adsorbents for dyes removal, $J$. Mol. Liq., 288, 110989.

[12] Badri, A.F., Palapa, N.R., Mohadi, R., and Lesbani, A., 2020, Cationic dye removal by magnesium aluminum-biochar composite from aqueous solution, Int. J. Sci. Technol. Res., 9 (7), 186-190.

[13] He, H., Zhang, N., Chen, N., Lei, Z., Shimizu, K., and Zhang, Z., 2019, Efficient phosphate removal from wastewater by MgAl-LDHs modified hydrochar derived from tobacco stalk, Bioresour. Technol. Rep., 8,100348 .

[14] Balcomb, B., Singh, M., and Singh, S., 2015, Synthesis and characterization of layered double hydroxides and their potential as nonviral gene delivery vehicles, ChemistryOpen, 4 (2), 137-145.

[15] Palapa, N.R., Juleanti, N., Normah, N., Taher, T., and Lesbani, A., 2020, Unique Adsorption properties of malachite green on interlayer space of $\mathrm{Cu}-\mathrm{Al}$ and $\mathrm{Cu}$ $\mathrm{Al}-\mathrm{SiW}_{12} \mathrm{O}_{40}$ layered double hydroxides, Bull. Chem. React. Eng. Catal., 15 (3), 653-661.

[16] Bamroongwongdee, C., Suwannee, S., and Kongsomsaksiri, M., 2019, Adsorption of Congo red from aqueous solution by surfactant-modified rice husk: Kinetic, isotherm and thermodynamic analysis, Songklanakarin J. Sci. Technol., 41 (5), 1076-1083.

[17] Alsamman, L., 2017, Development of Modified Layered Silicates with Superior Adsorption Properties for Uptake of Pollutants from Air and Water, Dissertation, RWTH Aachen University, Aachen, Germany.
[18] Siregar, P.M.S.B.N., Palapa, N.R., Wijaya, A., Fitri, E.S., and Lesbani, A., 2021, Structural stability of $\mathrm{Ni} / \mathrm{Al}$ layered double hydroxide supported on graphite and biochar toward adorption of Congo red, Sci. Technol. Indones., 6 (2), 85-95.

[19] Wan Ngah, W.S., and Hanafiah, M.A.K.M., 2008, Adsorption of copper on rubber (Hevea brasiliensis) leaf powder: Kinetic, equilibrium and thermodynamic studies, Biochem. Eng. J., 39 (3), 521-530.

[20] Palapa, N.R., Taher, T., Wijaya, A., and Lesbani, A., 2021, Modification of $\mathrm{Cu} / \mathrm{Cr}$ layered double hydroxide by Keggin type polyoxometalate as adsorbent of malachite green from aqueous solution, Sci. Technol. Indones., 6 (3), 209-217.

[21] Sahmoune, M.N., 2019, Evaluation of thermodynamic parameters for adsorption of heavy metals by green adsorbents, Environ. Chem. Lett., 17 (2), 697-704.

[22] Mahmoodi, N.M., Abdi, J., and Bastani, D., 2014, Direct dyes removal using modified magnetic ferrite nanoparticle, J. Environ. Health Sci. Eng., 12 (1), 96.

[23] Hashem, A., Ahmad, F., and Badawy, S.M., 2016, Adsorption of direct green 26 onto fix 3500 treated sawdust: Equilibrium, kinetic and isotherms, Desalin. Water Treat., 57 (28), 13334-13346.

[24] Yu, J., Zhang, X., Wang, D., and Li, P., 2018, Adsorption of methyl orange dye onto biochar adsorbent prepared from chicken manure, Water Sci. Technol., 77 (5), 1303-1312.

[25] Tran, T.V., Phan, T.Q.T., Nguyen, D.T.C., Nguyen, T.T., Nguyen, D.H., Vo, D.V.N., Bach, L.G., and Nguyen, T.D., 2020, Recyclable $\mathrm{Fe}_{3} \mathrm{O}_{4} @ \mathrm{C}$ nanocomposite as potential adsorbent for a wide range of organic dyes and simulated hospital effluents, Environ. Technol. Innovation, 20, 101122.

[26] Nazir, M.A., Khan, N.A., Cheng, C., Shah, S.S.A., Najam, T., Arshad, M., Sharif, A., Akhtar, S., and Ur Rehman, A., 2020, Surface induced growth of ZIF67 at Co-layered double hydroxide: Removal of methylene blue and methyl orange from water, Appl. Clay Sci., 190, 105564. 
[27] Hua, P., Sellaoui, L., Franco, D., Netto, M.S., Luiz Dotto, G., Bajahzar, A., Belmabrouk, H., BonillaPetriciolet, A., and Li, Z., 2020, Adsorption of acid green and procion red on a magnetic geopolymer based adsorbent: Experiments, characterization and theoretical treatment, Chem. Eng. J., 383, 123113.
[28] Nazifa, T.H., Habba, N., Salmiati, S., Aris, A., and Hadibarata, T., 2018, Adsorption of procion red MX-5B and crystal violet dyes from aqueous solution onto corncob activated carbon, J. Chin. Chem. Soc., 65 (2), 259-270. 